\section{Verdifullt om legenes spesialisering}

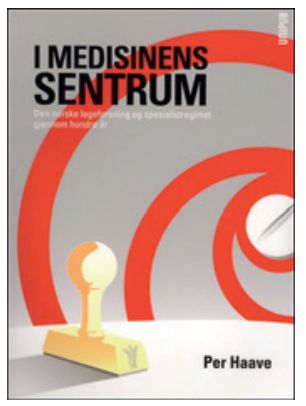

\section{Per Haave \\ I medisinens sentrum}

Den norske legeforening og spesialistregimet gjennom hundre år. $550 \mathrm{~s}$, tab, ill.

Oslo: Unipub, 2011. Pris NOK 398

ISBN 978-82-7477-512-1

Utdanning og godkjenning av spesialister innen medisinen har en lang historie. Spesialisering har vært et viktig fremskritt, men mange har også vært skeptiske til utviklingen. Vi har også bruk for generalister. Allerede før første verdenskrig var det en professor i anatomi ved Universitetet i Wien som så med uro på den økende spesialiseringen, og i forelesningene ordla han seg gjerne slik: «Mine damer og herrer. Som bekjent har det menneskelig legeme en rekke naturlige åpninger, og utenfor hver av dem lurer en spesialist!»

Historikeren Per Haave har skrevet en omfattende bok som for første gang gir oss en komplett oversikt over utdanning og godkjenning av legespesialister i Norge fra tidlig på 1900-tallet frem til 2011. Der har Den norske legeforening vært en sentral aktør gjennom mer enn 100 år. Ikke bare har den hatt hånd om spesialistutdanningen og godkjenningen av spesialister, men også vurdert hvilke spesialiteter og etter hvert subspesialiteter som skulle opprettes. Dessuten har foreningen organisert spesialistene i spesialforeninger og hatt klare synspunkter på reguleringen av tilgangen på spesialister. Et omfattende engasjement og atskillig idealisme har ligget til grunn, men samtidig er Legeforeningen blitt utsatt for økende kritikk. Utenfor den medisinske profesjonen ble det ofte vurdert som at bukken skulle passe havresekken. En rekke nye lover har gitt fullt ansvar og kontroll med spesialistutdanningen til det offentlige. Likevel har i praksis ordningen med å godkjenne spesialister vært delegert til Legeforeningen fra offentlige myndigheter. Denne rollen kunne komme i konflikt med Legeforeningens rolle som fagforening og kamporganisasjon for medlemmene.

Haave gir en omfattende fremstilling av denne utviklingen gjennom alle disse årene. Han refererer til sentrale aktører innen norsk helsevesen og ulike synspunkter som har vært fremmet gjennom tidene, og han forteller om den praktiske håndteringen av spesialistutdanningen. Mange andre aktører har også vært inne i bildet, alt fra de medisinske fakultetene til Sosialdepartementet, Helsedirektoratet og ulike politiske instanser. Helsedirektoratet fikk redusert posisjon i 1983 som medisinsk fagstyre i landet, men hadde fortsatt delegert ansvar for spesialistordningen fra Sosialdepartementet. Departementet overtok dette ansvaret i 1999 fra det reorganiserte Helsetilsynet (dvs. Helsedirektoratet inntil 1994), som imidlertid hadde rett til å delegere spesialistgodkjenningen videre. Den 1.10.2011 var det kroken på døren: Legeforeningens delegerte rolle opphørte, men den skulle fortsatt være sakkyndig konsulent for myndighetene ved behandling av spesialistsøknader.

Gjennom denne 100-årsperioden plasserte Den norske legeforening seg i medisinens sentrum, slik Haave uttrykker det. Det var ikke som kunnskapsprodusent, men som en kvalifiserende, sertifiserende og akkrediterende samfunnsmakt. Han legger til at helsemyndighetene på sin side ga foreningen et stort handlingsrom, selv etter en regulering fra 1982 med innføringen av ny kommunehelsetjenestelov. Fra 2011 tok altså en æra slutt: Legeforeningen skulle ikke lenger godkjenne leger som spesialister og heller ikke resertifisere spesialister i allmennmedisin.

Med sine over 500 sider og tallrike referanser er boken et verdi- fullt kildedokument som vil bli stående for ettertiden. Her finnes et vell av opplysninger, ikke bare om spesialistutdanningen, men også om historikken bak Legeforeningens roller ved utviklingen av helsevesenet i Norge. Jeg anbefaler den for både leger og andre med interesse for helsepolitikk og legeutdanning.

Med sin detaljrikdom er den likevel mer av verdi som historisk referanseverk enn som sengelektyre. Haave har belyst en viktig rolle som Legeforeningen har spilt gjennom tidene. Kanskje er det en lettelse for foreningen at den ikke lenger skal ha en slik dobbeltrolle. Nå kan den konsentrere seg mer om fagforenings- og helsepolitiske spørsmål og klarere hevde partsinteressene sine.

Haave er klart kritisk til Legeforeningens mange roller og rolleblanding, slik en historiker skal være. Men jeg savner en vurdering av den instansen som har overtatt oppgavene: Helsemyndighetene har også partsinteresser og er dessuten underlagt politiske føringer og vedtak. Også her kan det oppstå interessekonflikter og dobbeltroller, og jeg er ikke helt sikker på at den offentlige bukken er bedre til å passe havresekken enn den private. Best går det vel når forholdene er ryddige, samtidig som de ulike aktørene passer på hverandre. Uansett: Gratulerer Per Haave med et velgjort arbeid!

\section{Ole Didrik Lærum}

Voss

\section{Avansert lærebok om autisme}

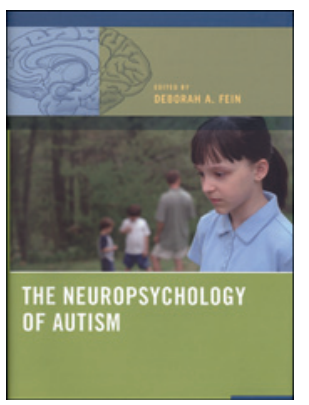

\author{
Deborah A. Fein, red.
}

The neuropsychology of autism

540 s, tab, ill. Oxford: Oxford University Press,

2011. Pris GBP 50

ISBN 978-0-19-537831-3

Deborah Fein er professor i psykologi ved University of Connecticut. Hun er en anerkjent nevropsykolog med mer enn 35 års erfaring som kliniker og forsker innen autisme. Tyngdepunkter i hennes forskning er nevropsykologi i autismespekterlidelser og nevropsykologisk utredning. Hun har publisert over 100 artikler og bokbidrag, og dette er hennes andre bok om autisme.

Boken kan betegnes som en avansert lærebok, og målgruppen er studenter, klinikere og forskere med interesse for autisme. Ledende internasjonale eksperter i feltet gir leseren et vidt spenn av informasjon, fra mer kjente områder som sosial interaksjon, språk, oppmerksomhet, arbeidsminne, eksekutivfunksjoner og nevroanatomi til nyeste viten innen genetikk, strukturell og funksjonell hjerneutvikling, nevropeptider, steroider etc. I et eget kapittel drøfter hun mer systemisk tilnærming til lidelsen, noe som er spennende å lese og meget tankevekkende.

Kapitlene er detaljerte, men oversiktlige, og man kan fint lese dem hver for seg. Teksten formidler forholdsvis tung informasjon på en lett tilgjengelig måte. Teksten suppleres av tabeller, illustrasjoner og mange aktuelle litteraturkilder. Per i dag er det få liknende bøker på markedet, og jeg kan trygt anbefale boken for fagfolk som ønsker å fordype seg i emnet.

Uta Bastian

BUPA Nordlandssykehuset 